\title{
On the centenary of the term "hormone"
}

\author{
Effie Poulakou-Rebelakou, Costas Tsiamis, Spyros G. Marketos
}

History of Medicine, Athens University, Medical School

\section{INTRODUCTION}

In June of 2005 the term hormone completed a life span of one century. The word that Ernest Henry Starling included in one of his four lectures to the Royal Society of Physicians of London, given in June 1905, definitively established the permanent representation in terminology for the products secreted by the endocrine glands. Various attempts by physicians and medical writers to replace the term hormo$n e$ by others such as chalones (Sir Albert Schaefer), autacoids (W.R. Wardle), harmozones (Eugene Gley $)^{1}$, have failed and have more or less been forgotten, none of these terms havimg been adopted universally ${ }^{2}$.

\section{E.H. STARLING AND THE TERM "HORMONE"}

Ernest Henry Starling (1866-1927) was appointed to the Chair of Physiology at University College of London (UCL) in 1899, a post he held until 1923. It is no exaggeration to say that in 1828 a "dynasty" in Physiology was established at UCL comprising such personalities as Charles Bell (first Professor of Physiology), William Sharpey, John Burdon Sanderson (who had the honour of collaborating with

Key words: E.H. Starling, Hormone, Medical terminology

Address correspondence and requests for reprints to: Costas Tsiamis, 104 Formionos Str., Athens 16231, Greece, e-mail: ctsiamis@in.gr

Received 01-07-05, Revised 20-07-05, Accepted 22-07-05
William Osler when the latter spent 18 months in England), William Bayliss and Edward Scaefer ${ }^{3}$.

Starling (Figure 1) in 1898 had just been elected to the Royal Society for his work on the formation of the lymph. He demonstrated that the outward hydrostatic forces in the capillary were opposed by inward osmotic forces brought about by plasma proteins (Starling's Principle) $)^{4}$. He was the first to introduce the concept of oncotic pressure and to appreciate the counterbalancing of hydrostatic and oncotic pressure on transcapillary fluid exchange. In collaboration with his brother-in-law, William Bayliss, he investigated the inervation and movements of the small intestine and made the first significant descriptions of peristalsis ${ }^{4}$. Starling also studied the nature of secretin, an internal secretion deriving from the mucous membrane of the intestine and not from a secreting gland. In 1904 the term endocrinology was used for the first time by Maurice-Adolphe Limon, produced from the Greek

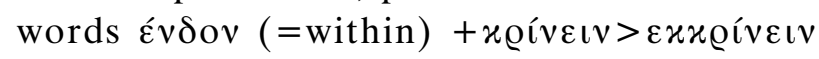
$(=$ sift $)+\lambda o ́$ os (=speech) denoting $-\operatorname{logy}=$ a subject of study.

Presumably because of the discovery of secretin, Starling was asked to give the Croonian Lecture to the Royal Society. He delivered four lectures in which he reviewed the whole endocrinological scene including a good deal of his own work. The four oral presentations were published in "The Lancet" on August $5^{\text {th }}, 12^{\text {th }}, 19^{\text {th }}$ and $26^{\text {th }}$ respectively, under the general title "The chemical correlation of the functions of the body".

In the first lecture (Figure 2) he states the fol- 


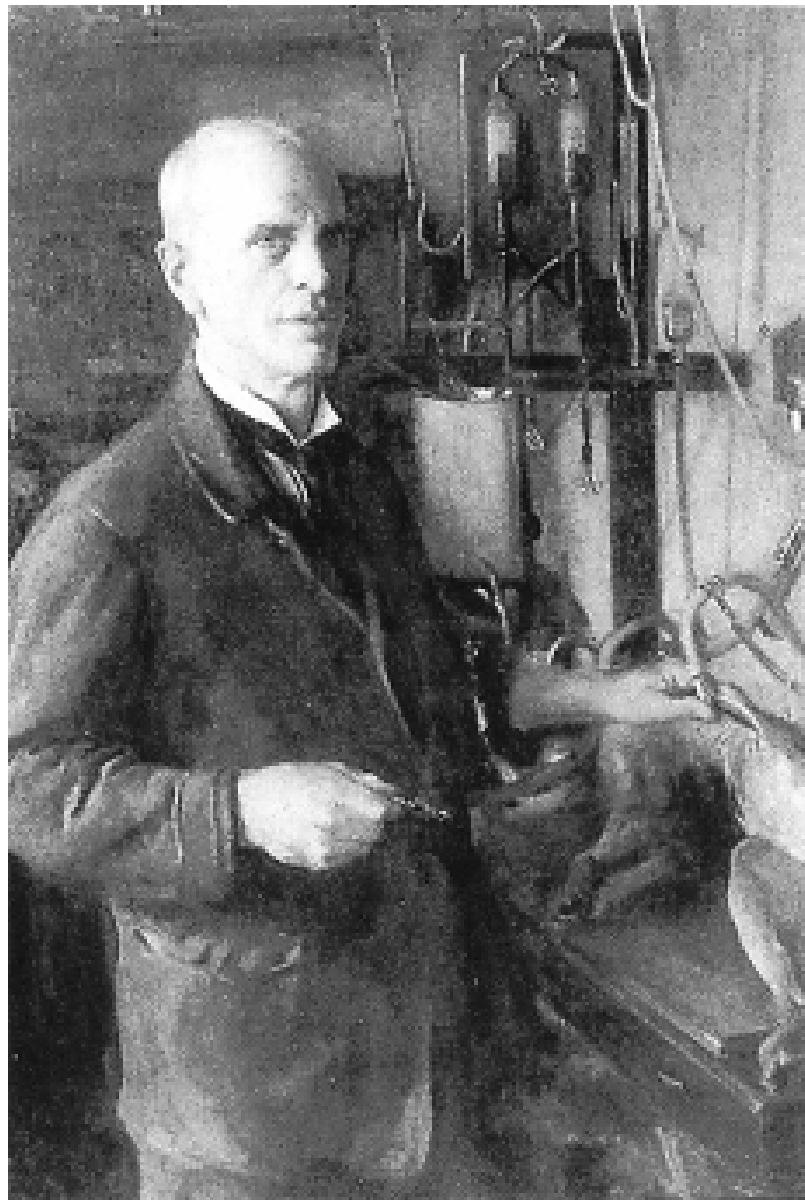

Figure 1. E.H. Starling (1866-1927), the great physiologist.

lowing: "These chemical messengers, however, or $<$ hormones $>$ (from oQ $\mu \alpha \dot{\omega} \omega=$ I excite or arouse), as we might call them, have to be carried from the organ where they are produced to the organ which they affect by means of the blood stream and the continually recurring physiological needs of the organism must determine their repeated production and circulation through the body" . He does not use the term hormones in lectures II and III $^{7,8}$ and repeats it only in the fourth lecture, not merely once but 17 times.

An interesting story concerning the genesis of the term hormone was narrated by the distinguished Cambridge biochemist Joseph Needham in his book Order and Life (1936). Starling was invited to dinner at Caius College Cambridge by the eminent biologist W.B. Hardy. During their conversation both decided that they needed a word for an agent re-

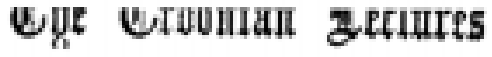 \\ ax \\ THE CHEMICAL CORRELATION OF THB FUNCIIONS OF THB BODY. \\ Dodinerad before the Rogel Conge of PAyricians of Losdow on Jwhe toth, and, s7et, and omth, 1005, By ERNEST HENRY STARLING, M.D. LoND.,
F.R.S.,

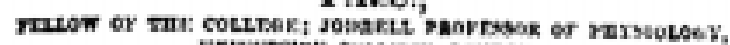 Exivenry cuLasi, 20xpos. \\ LBCTURE I. \\ Delinered au Jane wee.}

Tur Ogencal Costaol of rue Fuxctioss of tare Dody.

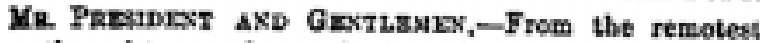
aga the exlateoce of a profession of medieine, the practioe $\alpha$ its art and its aceeptance as a necessary part of every commenity have boen foededed of a tacit assumption that the fanetions of the body, whetlior of growth or activity of organs, can bo controllexl by chemicul metus ; and researel. by observation of accident or by experiment for such means has reaulted in the lioge array of drugk which form the pharmaoppoins of various eivilised countries and the common armamentarias of the medienl professien througls. eet the world.

Figure 2. In Introduction to Starling's lecture, given on June 20 $1905^{6}$, and published in "The Lancet".

leased into the blood stream that stimulated activity in a different part of the body. They asked help of their colleague W.T. Vesey, an authority on Greek classical studies and especially on the work of the ancient poet Pindar, who frequently used the Greek

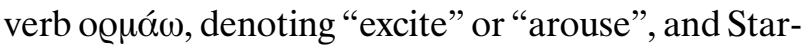
ling conserved the term in his note-book and in his mind until his first lecture. The author does not give the exact date of this historical dinner, thus the time between it and the first appearance of the word hormone remains unknown. It is probable that Needham was present at the dinner or that the story was told to him by another who heard it himself ${ }^{4}$.

It is noteworthy that John Smith of Brasenose College at Oxford had used the word hormetic 250 years before, in 1666, in the phrase "the hormetic power and contraction of the muscles". The verb

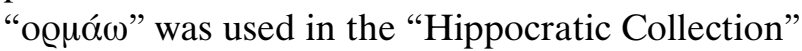
with the same meaning (=to rush, to set in motion) ${ }^{10}$. For example, in the famous Hippocratic Treatise "Sacred Disease" it is mentioned that the corruption of the brane is caused by the phlegm and the

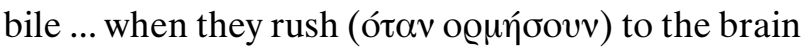


from the rest of the body by way of the veins ${ }^{10}$.

\section{CONCLUSION}

The Greek term hormone was first used in medical terminology in a series of articles by the famous physiologist Ernest Henry Starling published in "The Lancet" (1905). The 100th anniversary of the term hormone reveals that his contribution by way of the coining of the term hormone is of no less importance than his enormous medical contribution to human physiology.

\section{REFERENCES}

1. Castigloni A 1961 History of Medicine. Minotaurus, Athens; pp, 984-990 (in Greek).

2. Ikkos DG 2000 Endocrinology over the last 150 years, a lecture on the $150^{\text {th }}$ anniversary of the Athens University Medical School, 24.9.1987 in Marketos SG History of Medicine of the $20^{\text {th }}$ Century. The Greek Pio- neers 4, Dennis Ikkos, Zeta (ed), Athens; pp 86-89.

3. Fine LG, 1999 British Contributions to Renal Physiology: of Dynasties and Diuresis. Am J Nephrol 19: 257265.

4. Henderson J, 2005 Ernest Starling and "Hormones": an historical commentary. J Endocrinol 184: 5-10.

5. Poulakou-Rebelakou E, Marketos SG, 2002 Endocrine terminology in Corpus Hippocraticum. Hormones 1 : 57-58.

6. Starling EH, 1905 The Chemical Correlation of the functions of the body, Lecture I. The Lancet 2: 339341.

7. Starling EH, 1905 The Chemical Correlation of the functions of the body, Lecture II. The Lancet 2: 423425.

8. Starling EH, 1905 The Chemical Correlation of the functions of the body, Lecture III. The Lancet 2: 501503.

9. Starling EH, 1905 The Chemical Correlation of the functions of the body, Lecture IV. The Lancet 2: 579583.

10. Apostolides PD 1997 Lexicon of all the Hippocratic words. Gabrielides (ed), Athens (in Greek). 